\title{
Echoes from the past - the identity of Sundathelphusa picta (von Martens, 1868) and descriptions of two new species of freshwater crab (Crustacea, Brachyura, Gecarcinucidae, Sundathelphusa) from Luzon Island, the Philippines
}

\author{
Peter K. L. $\mathrm{Ng}^{1}$ \& Jose Christopher E. Mendoza,
}

\begin{abstract}
The poorly known Philippine freshwater crab, Sundathelphusa picta (von Martens, 1868) from Luzon Island is redescribed and re-illustrated, using type material as well as other specimens sampled from near its type locality. Two similar congeners from Luzon, S. uva sp. nov. and $S$. angelito sp. nov., from the provinces of Bataan and Rizal, respectively, are described as new. These three species are united by their relatively small size, rounded and dome-shaped carapaces, proportionately short ambulatory legs, and stout male first gonopods. They are distinguished from each other by a suite of morphological characters, particularly of the carapace, male pleon and gonopods.
\end{abstract}

Keywords: Decapoda, Sundathelphusa uva, Sundathelphusa angelito, taxonomy, Bataan, Bicol, Rizal

\section{Introduction}

Sundathelphusa Bott, 1969, is one of the most species-rich gecarcinucid freshwater crab genera in Southeast Asia, with 40 recognised species. The Philippines harbours the greatest number of species by far, with 30 of the known taxa to date, all of which are country endemics ( $\mathrm{Ng}$ et al., 2008; Mendoza \& Naruse, 2010; Ng, 2010, 2015; Husana et al., 2014, 2015; Ng \& Anker, 2016; Mendoza \& Sy, 2017; Husana \& Ng, 2019).

In this paper, we describe two new species of Sundathelphusa from two parts of Luzon (in the provinces of Bataan and Rizal, respectively), collected about 150 years apart, but which are morphologically closest to each other. One species ( $S$. uva sp. nov.), represented by a single male specimen collected by German zoologist, Carl Semper, from a montane habitat near Mariveles, Bataan Province in the 1860s, has long been confused with another species - S. philippina (von Martens, 1868) (see Bürger, 1894; Husana \& Ng, 2019), and while its novel status has been known to the first author for 25

Lee Kong Chian Natural History Museum, Faculty of Science, National University of Singapore, 2 Conservatory Drive, 117377 , Singapore.

*Corresponding email: ${ }^{1}$ peterng@nus.edu.sg; ${ }^{2}$ jcmendoza@nus.edu.sg

Date Submitted: 15 August 2019

Date Accepted: 30 May 2020 years, it has nevertheless somehow remained undescribed. The other species ( $S$. angelito sp. nov.) is represented by several specimens which were independently collected from Rizal Province by the second author and local colleagues in 2011 and 2012, and it was subsequently realised that its closest congener was actually the undescribed Sundathelphusa from Mariveles. The two new species are both similar to S. picta (von Martens, 1868), a poorly known species originally described from the Bicol Peninsula in southeastern Luzon, and the opportunity is taken to redescribe it here and further clarify its taxonomy.

The present paper endeavours to address the echoes of past circumstances that have led to this interesting situation, with past, unfinished studies impacting and coinciding with recent discoveries. This coming together of past and present is also the ideal occasion to honour one of the most influential biologists the Philippines (and Southeast Asia) has ever known, whose impact on regional biodiversity has been singular. Every generation of practising taxonomists knows they owe a huge debt of gratitude to the giants that precede them. Angel Alcala is one of these giants.

\section{Materials and Methods}

The terminology used follows that in $\mathrm{Ng}$ (1988) and Davie et al. (2015). Measurements provided, in millimetres, are of the carapace maximum width and length at the midline, respectively. The abbreviations G1 and G2 are used for the male 
first and second gonopods, respectively. Specimens examined are deposited in the Crustacean Collection (NMCR) of the National Museum of Natural History, Manila; National Museum of Nature \& Science (NSMT), Tokyo; Forschungsinstitut Senckenberg (SMF), Frankfurt am Main; Museum für Naturkunde (ZMB), Berlin; and Zoological Reference Collection (ZRC) of the Lee Kong Chian Natural History Museum, National University of Singapore. Photographs were taken using a digital camera (Nikon Coolpix 995 or Nikon D850). Line drawings were done by camera lucida attached to a stereomicroscope (Leica M80), scanned at 600 dpi. All figures were organized and put together with Adobe Photoshop CS3 (ver. 10).

\section{Results}

\section{Taxonomy}

\section{Family Gecarcinucidae Rathbun, 1904}

\section{Genus Sundathelphusa Bott, 1969}

Type species. Potamon (Geothelphusa) cassiope De Man, 1902, by original designation (viz. $\mathrm{Ng}$ et al., 2008).

\section{Sundathelphusa picta (von Martens, 1868)}

(Figs. 1, 2)

\author{
Thelphusa picta von Martens, 1868: 611. - A. Milne-Edwards, 1869: 179. \\ Geotelphusa picta - De Man, 1892: 234. \\ Potamon (Geothelphusa) pictum - Ortmann, 1897: 314 (in part). \\ Potamon (Geothelphusa) pictus - Rathbun, 1905: 220. \\ Para-Lio-thelphusa picta-Balss, 1937: 149, fig. 4. \\ Parathelphusa (Liothelphusa) chilensis picta - Pretzmann, 1964: 490. \\ Sundathelphusa picta - Bott, 1970: 79, pl. 12 figs. 36-38, pl. 28 fig. 50. - Ng et \\ al., 2008: 73 (list). - Mendoza \& Naruse, 2010: 63, table 1.
}

Material examined. Lectotype, male $(22.5 \times 17.6 \mathrm{~mm})(\mathrm{ZMB}$ 1052a), Lake Bato, ca. $13^{\circ} 19^{\prime} \mathrm{N} 123^{\circ} 21^{\prime} \mathrm{E}$, Camarines Sur Province, Luzon, coll. F. Jagor, 1859-1860. Paralectotypes: 2 females $\left(20.6 \times 17.4 \mathrm{~mm}, 32.5^{\prime} 24.1\right.$ $\mathrm{mm}$ ) (ZMB 1052b), same data as lectotype.

Other material: 2 males (larger, $18.7 \times 15.9 \mathrm{~mm}$; smaller not measured), 3 females (not measured) (ZMB 1056), Kalobos creek, Albay Province, Luzon, coll. F. Jagor, 1859-1860; 8 males, 5 females (not measured) (ZMB 5593), Kalobos creek, Albay Province, Luzon, no other data; 10 males, 1 female (22.3 $\times 18.0 \mathrm{~mm})(\mathrm{NSMT}), 2$ males $(19.1 \times 15.7 \mathrm{~mm}, 21.7 \times 17.8$ $\mathrm{mm}), 1$ female $\left(18.8^{\prime} 15.7 \mathrm{~mm}\right)$ (ZRC 2019.1352), 1 male (27.0 $\times 21.6 \mathrm{~mm}), 1$ female $(23.6 \times 18.8 \mathrm{~mm})($ ZRC 2019.1353), Binangkaan River, Buhi, ca. $13^{\circ} 26^{\prime} \mathrm{N} 123^{\circ} 31^{\prime} \mathrm{E}$, Camarines Sur Province, Luzon, coll. M. Takeda, 19 August 1985.

Diagnosis. Carapace subtrapezoidal, rounded, wider than long (carapace width-to-length ratio 1.2-1.3); anterolateral margin strongly convex, posterolateral margin nearly straight; dorsal surface distinctly convex, mostly smooth, gastric region inflated, branchial region inflated, weakly striated; epigastric, postorbital cristae poorly developed; cervical grooves moderately deep, broad; H-shaped gastrocardiac groove well defined. Frontal median triangle present but not sharply defined, dorsal margin not cristate, not contiguous with lateral margins. Exorbital angle broadly triangular, external margin gently convex. Epibranchial tooth small, separated from exorbital tooth by wide V- or Ushaped gap. Male pleonal somite 6 subrectangular, slightly longer than wide, lateral margins concave; telson with lateral margins slightly to moderately concave. G1 short, relatively stout, wide proximally, tapering towards distal tip and slightly curving laterally; terminal segment about one-third total length of G1, subconical, with distal tip abruptly narrowed, lateral margin slightly concave; joint between terminal, subterminal segments incomplete, transversely curved from sternal view. G2 terminal segment moderately long, about one-third total length of $\mathrm{G} 2$.

Description. Carapace (Figs. 1A, B) subtrapezoidal in outline, rounded, width-to-length ratio about 1.2-1.3, widest at level of mesobranchial region; dorsal surface mostly smooth, sparsely pitted, strongly convex longitudinally, moderately convex transversely; gastric, branchial, sub-branchial regions distinctly inflated; cardiac, intestinal regions gently convex; epigastric region without well-defined cristae, rather with grouping of discrete pits forming rugose area; postorbital cristae low, poorly developed; lateral regions with weak striation; shallow median groove between epigastric regions, cervical groove moderately deep, broad, H-shaped gastrocardiac groove shallow but distinct. Front moderately broad, about 0.3 times greatest carapace width, gently deflexed ventrally; anterior margin appearing concave in dorsal view; frontal median triangle (Fig. 1C, 2A; slightly damaged in holotype) poorly defined, dorsal margin not cristate, not fusing with lateral margins. Exorbital tooth broadly triangular, external margin weakly convex, distinctly longer than internal margin; epibranchial tooth small but distinct, triangular, with wide $\mathrm{V}$ - or U-shaped notch separating it from external orbital tooth. Anterolateral margin weakly cristate, strongly convex; posterolateral margin nearly straight, converging gradually towards posterior margin of carapace; central region of posterior margin slightly concave. Orbital margins cristate, supraorbital margin smooth, infraorbital margin finely granulate. Suborbital, sub-branchial, pterygostomial regions rugose, with rows of small granules. Posterior margin of epistome (Fig. 1C) with protruding, triangular median lobe with rounded tip, separated from sinuous lateral lobes by thin sutures. 


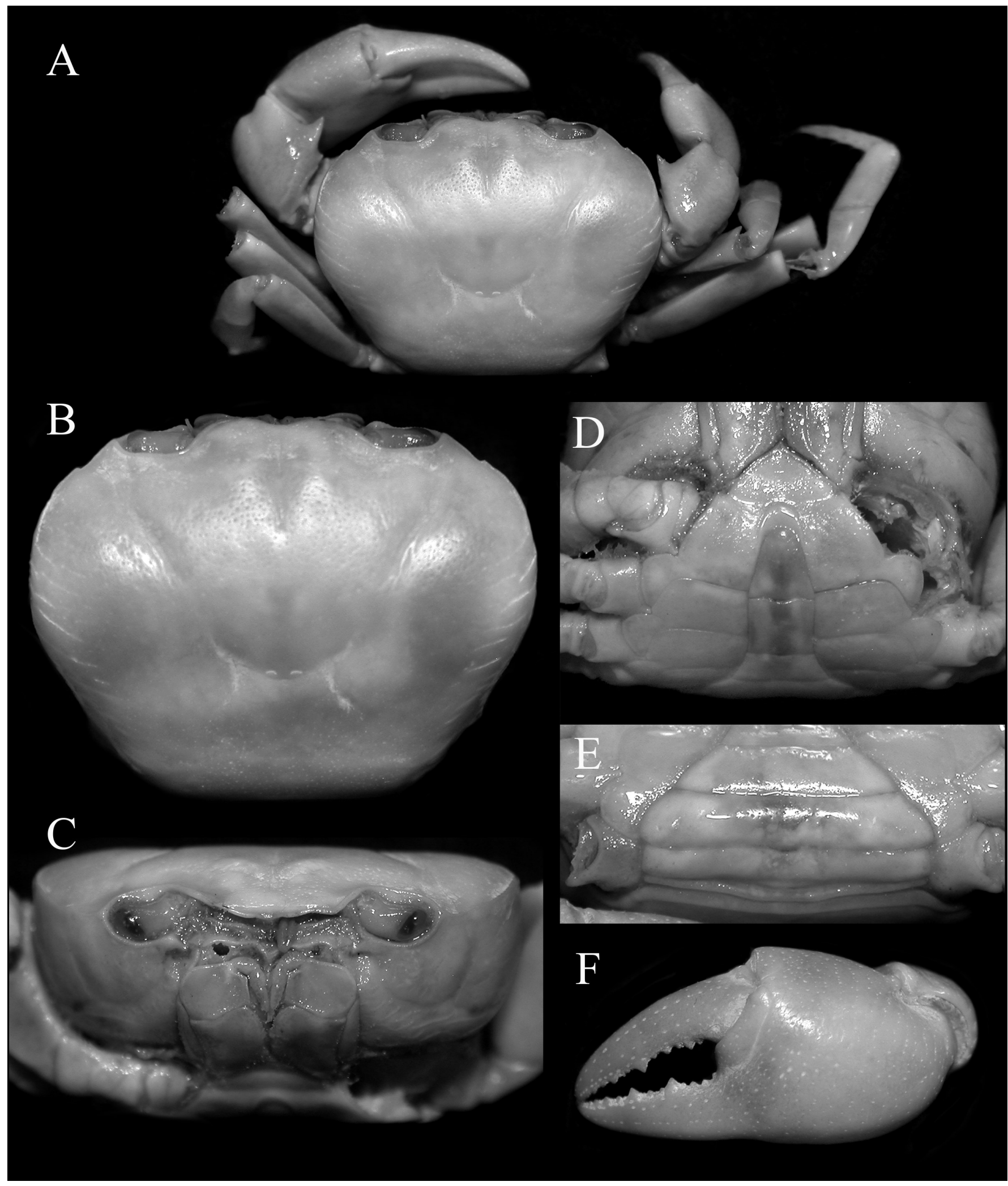

Figure 1. Sundathelphusa picta (von Martens, 1868), (A-F) lectotype, male (22.5 × $17.6 \mathrm{~mm})(\mathrm{ZMB} 1052)$, Lake Bato, Luzon I. A, dorsal habitus; B, carapace, dorsal view; C, carapace, anterior view; D, thoracic sternum \& pleon, ventral view; E, pleon, postero-ventral view; F, major (left) chela, external view. 


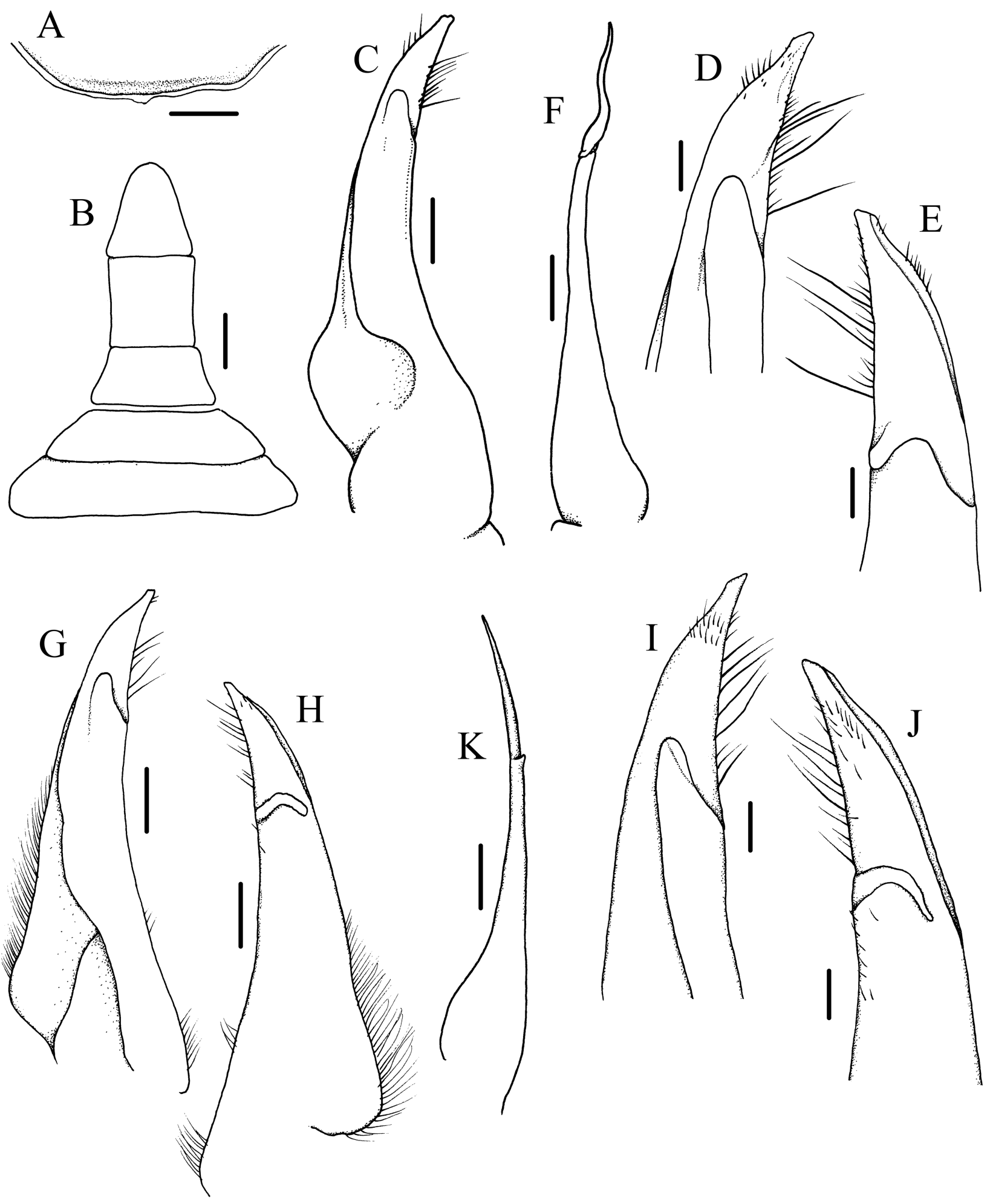

Figure 2. Sundathelphusa picta (von Martens, 1868), (A-F) lectotype, male (22.5 × $17.6 \mathrm{~mm})$ (ZMB 1052), Lake Bato, Luzon I.; (G-J) male $(21.7 \times 17.9$ mm) (ZRC 2019.1352), Binangkaan River, Buhi, Luzon I. A, front, anterior view; B, pleon (somites 3-6 \& telson only), ventral view; C, G, left G1, pleonal view; H, left G1, sternal view; D, I, distal tip of left G1,pleonal view; E, J, distal tip of left G1, sternal view; F, K, left G2, pleonal view. Scales: A, B = $2.0 \mathrm{~mm}$; C, F-H, K = $0.5 \mathrm{~mm}$; D, E, I, J = 0.2 $\mathrm{mm}$. 
Eyes (Figs. 1B, C) large, occupying almost entire orbit, corneas well developed. Mandibular palp with two segments, terminal segment bilobed, inner lobe about one-third longer than outer lobe, both lobes broad, flattened. Third maxilliped (Fig. 1C) sparsely setose; ischium subrectangular, with distinct, oblique, submedian sulcus closer to mesial margin; merus subquadrate, distal (anterior) margin slightly sinuous, almost straight, lateral margin convex, lateral, mesial and proximal margins raised, central region depressed; exopod slender, appearing distally tapering when pressed against lateral margins of endopod, external margin slightly sinuous, distal tip reaching level of mid-length of merus, with small subtriangular projection on subdistal inner margin, flagellum well developed, reaching mesial margin of merus.

Male thoracic sternum (Fig. 1D) broad, generally smooth; sternites 1-4 fused, traces of sutures between sternites 2, 3 and 3, 4 seen as deep transverse grooves; sternite 4 with slightly convex lateral margins, slightly raised area around anterior portion of sternopleonal cavity. Sternopleonal cavity deep; press -button on sternite 5, midway between sutures.

Chelipeds, P1 (Fig. 1A), distinctly asymmetric (in males), robust; merus lower (ventral) surface gently striated with rows of fine granules continuing onto posterior margin, anterior margin ratcheted with short transverse rows of fewer, larger granules; upper surface of carpus lightly striated, with small scattered pits, inner angle with short, pointed tooth, followed by one or two large granules proximally; palm of major chela (Fig. 1F) inflated, with smooth dorsal, external, internal surfaces, inferior margin distinctly convex, with distinct junction with fixed finger; palm of minor chela smaller, less inflated; fingers sparsely pitted, slender, distal tips pointed, crossing, gape moderately wide, cutting edges armed with several small teeth interspersed with slightly larger teeth, no molariform teeth, dactylus longer than superior margin of palm.

Ambulatory legs, P2-P5, relatively short, P3 longest, total length (coxa-dactylus) about 1.3 times maximum carapace width, P5 shortest, total length (coxa-dactylus) about 1.1 times maximum carapace width; anterior margins of meri weakly serrated, with low subdistal angle not distinctly formed into tooth or spine, posterior margins smooth, subcristate only on P4, P5; carpus short, with longitudinal submedian ridge on dorsal surface except for P5, widened distally; propodus flattened, anterior, posterior margins with spiniform setae; dactylus slender, slightly curved at distal tip, subequal in length to propodus, with several spiniform, marginal setae.

Male pleon (Figs. 1D, E, 2B) shaped like inverted ' $T$ ', moderately broad for the genus; somite 1 thin, sinuous; somites 2-5 subtrapezoidal, progressively narrowing distally; somite 6 subrectangular, proximal width equal to distal width, median length 1.1 times maximum width, lateral margins slightly concave, slightly divergent anteriorly; telson subtriangular, apex rounded, lateral margins slightly to moderately convex, basal width subequal to median length, distal tip reaching to level of posterior quarter of $\mathrm{P} 1$ coxae in ventral view.

G1 (Figs. 2C-E, G-J) short, stout, wide at base, tapering distally and curving laterally; subterminal segment slightly curved, mesial margin gently convex, lateral margin gently concave; suture between terminal, subterminal segments curved; terminal segment distinctly curving laterally, about 0.3 times total length, subconical, lateral margin slightly concave, distal tip abruptly narrowed compared to proximal areas. G2 (Figs. 2F, $\mathrm{K})$ slender, tapering distally; terminal segment moderately long, about 0.3 times total length.

Remarks. Thelphusa picta was described by von Martens (1868: 611) from an unspecified number of specimens from "See Bato, Provinz Camarines Sur, Insel Luzon" [= Lake Bato, Camarines Sur Province, Luzon Island]. The crabs were collected by the German ethnologist, Fedor Jagor, probably sometime in 1859 and 1860 , the years when he was travelling through the Philippines, including Camarines Sur (see Jagor, 1875). Von Martens (1868) also indicated that the material was catalogued in the Berlin Zoological Museum (today's ZMB) as "Berl. Zool. Mus. 1052". He did not accompany his description with a figure, nor did he indicate a type specimen nor how many specimens he examined, although he did mention that the carapace dimensions of one specimen was $30 \mathrm{~mm}$ wide and 25 $\mathrm{mm}$ long. All material examined by von Martens, therefore, are syntypes.

Subsequent authors (De Man, 1892; Ortmann, 1897; Rathbun, 1905; Balss, 1937; Pretzmann, 1964) discussed this species, primarily on the aspect of its generic classification. It was Balss (1937: 149, fig. 4) who provided the first photograph of a type specimen (a male) and indicated that there was one type lot, "Mus. Berlin Nr. 1057" [sic.], which contained three type specimens ( 1 male and 2 females), he also provided the measurements of these specimens, of which the largest female, measuring 32.5 by $24.0 \mathrm{~mm}$, matches the specimen indicated in von Martens (1868). Significantly, in the caption to his figure, Balss (1937: fig. 4) wrote the specimen's catalogue number as "Museum Berlin Nr. 1052". Balss (1937) also mentioned a second lot, "Mus. Berlin Nr. 1056" containing several specimens that were initially identified as "Potamon philippinum" but which he clearly considered as conspecific with the types of S. picta, although it seems he did not regard the former as types.

It was Bott (1970: 80, pl. 12 figs. 36-38, pl. 28 fig. 50) who subsequently designated a lectotype from the series from 
Lake Bato deposited in the same museum - a male, which he reported as measuring " 18 by $16 \mathrm{~mm}$ ". He listed the catalogue number as "MBe 1057". A search by the first author showed, however, that there are no specimens of $S$. picta in the ZMB catalogued under number " 1057 ". Instead, there is the single syntype lot of $S$. picta collected by Jagor, viz. ZMB 1052 from Lake Bato (1 male, 2 females); this lot contains only one adult male, measuring 22.5 by $17.6 \mathrm{~mm}$, and also has a label containing the word "lectotype". Another lot, ZMB 1056, contains 2 males and 3 females collected from "Bach Kalobos, Albay", with the larger male measuring 18.7 by $15.9 \mathrm{~mm}$. However, as none of these specimens, their catalog number, nor their locality were referred to by von Martens (1868), they cannot be syntypes. The size of the Lake Bato male labelled as lectotype does not agree with the measurements provided by Bott (1970: 80), viz. "18 by $16 \mathrm{~mm}$ ". In fact, Bott's measurements match well with that of the larger male from Kalobos (ZMB 1056; here measured as 18.7 by $15.9 \mathrm{~mm}$ ). As such, the male specimen figured by Bott (1970: pl. 12 figs. 3638, pl. 28 fig. 50) is clearly not the same as the present lectotype. Balss' (1937: fig. 4) figure, however, exactly matches the present lectotype. It is almost certain, therefore, that the catalogue number, "1057" listed in Balss (1937: 149) and Bott (1970: 80) for the type/lectotype is an erroneous transcription of "1052". Bott had most probably also reported the wrong measurements ( 18 by $16 \mathrm{~mm}$, instead of 22.5 by $17.6 \mathrm{~mm}$ ) and provided the wrong photograph for the lectotype. In this, we place greater weight on von Marten's original reference to lot number "1052", Balss' measurements of the syntypes, and Bott's statement that his designated lectotype male was from Lake Bato, as well as the actual presence of the label "lectotype' in the jar for ZMB 1052, and consider them the best indicators of the lectotype status of the sole male specimen in that lot.

See General Discussion for taxonomy.

\section{Sundathelphusa uva sp. nov.}

(Figs. 3, 4)

Telphusa philippina - Bürger, 1894: 4 (in part). Not Thelphusa philippina von Martens, 1868.

Material examined. Holotype, male $(16.1 \times 13.0 \mathrm{~mm})$ (SMF-MGo 941c), Mariveles, mountain stream, ca. $14^{\circ} 26^{\prime} \mathrm{N}$ $120^{\circ} 30^{\prime}$ E, Bataan Province, Luzon I., Philippines, $1000 \mathrm{~m}$ asl, coll. C. Semper, 1858-1865.

Diagnosis. Carapace (Figs. 3A-C) subtrapezoidal, rounded, wider than long (carapace width-to-length ratio 1.2); anterolateral margins strongly convex, posterolateral margin distinctly concave; dorsal surface distinctly convex, mostly smooth, gastric region inflated, branchial region inflated but lower relative to gastric region in anterior view, weekly striated; epigastric, postorbital cristae poorly developed; cervical grooves moderately deep, broad; H-shaped gastrocardiac groove well defined. Frontal median triangle (Figs. 3C, 4B) present but not sharply defined, dorsal margin not cristate, not contiguous with lateral margins. Exorbital angle broadly triangular, external margin gently convex. Epibranchial tooth small, separated from exorbital tooth by wide, shallow V-shaped gap. Male pleonal somite 6 (Fig. 4C) subrectangular, slightly longer than wide, lateral margins slightly concave; telson subtriangular, basal width subequal to median height, with lateral margins straight, slightly convergent anteriorly for most of length, apex obtuse, broadly rounded. G1 (Fig. 4D-H) short, relatively stout, wide proximally, tapering towards distal tip, slightly curving laterally; terminal segment about one-third total length of G1, bent laterally away from main axis of subterminal segment, subconical, with distal tip abruptly narrowed, lateral margin convex, bulging distinctly; joint between terminal, subterminal segments complete, straightly transverse from sternal view. G2 (Fig. 4I) terminal segment moderately long, more than one-third total length of G2.

Etymology. The specific epithet $u v a$, derived from the Latin for grape, alludes to the round outlines of the carapace of the new species. The name is used as a noun in apposition.

Remarks. In his report on the genus "Telphusa", Bürger (1894: 4) included a brief account on what he called "Telphusa philippina $\mathrm{v}$. Martens", stating that: "There are a large number of these in our collection, which come from different parts of the Philippines (Rio Agno [Luzon], Mariveles and Palanan [Luzon], Camiguin [a small island in the northern neighbourhood of Luzon]). They are based on the original specimens of $T$. philippina and have been compared and completely agree with them." [translated from the original German]. He also included a figure (dorsal habitus and pleon) of a male specimen (Bürger, 1894: pl. 1 fig. 3).

Balss (1937: 156, 157) included Bürger's record of Telphusa philippina in his synonymy for a new subspecies he was describing, Para-Bary-thelphusa grapsoides longipes (currently Sundathelphusa longipes), on the basis of Bürger's figure (Bürger, 1894: pl. 1 fig. 3), which Balss noted to be quite similar to his type material for $S$. longipes.

Husana \& Ng (2019: 321) noted that the material from different islands reported as Telphusa philippina by Bürger (1894) actually belonged to four different species: viz. $S$. 




Figure 3. Sundathelphusa uva sp. nov., holotype, male $(16.1 \times 13.0 \mathrm{~mm})($ SMF-MGo 941c), Mariveles, Bataan, Luzon I. A, dorsal habitus; B, carapace, dorsal view; C, carapace, anterior view; D, thoracic sternum and pleon, ventral view; E, major (right) chela, external view. 


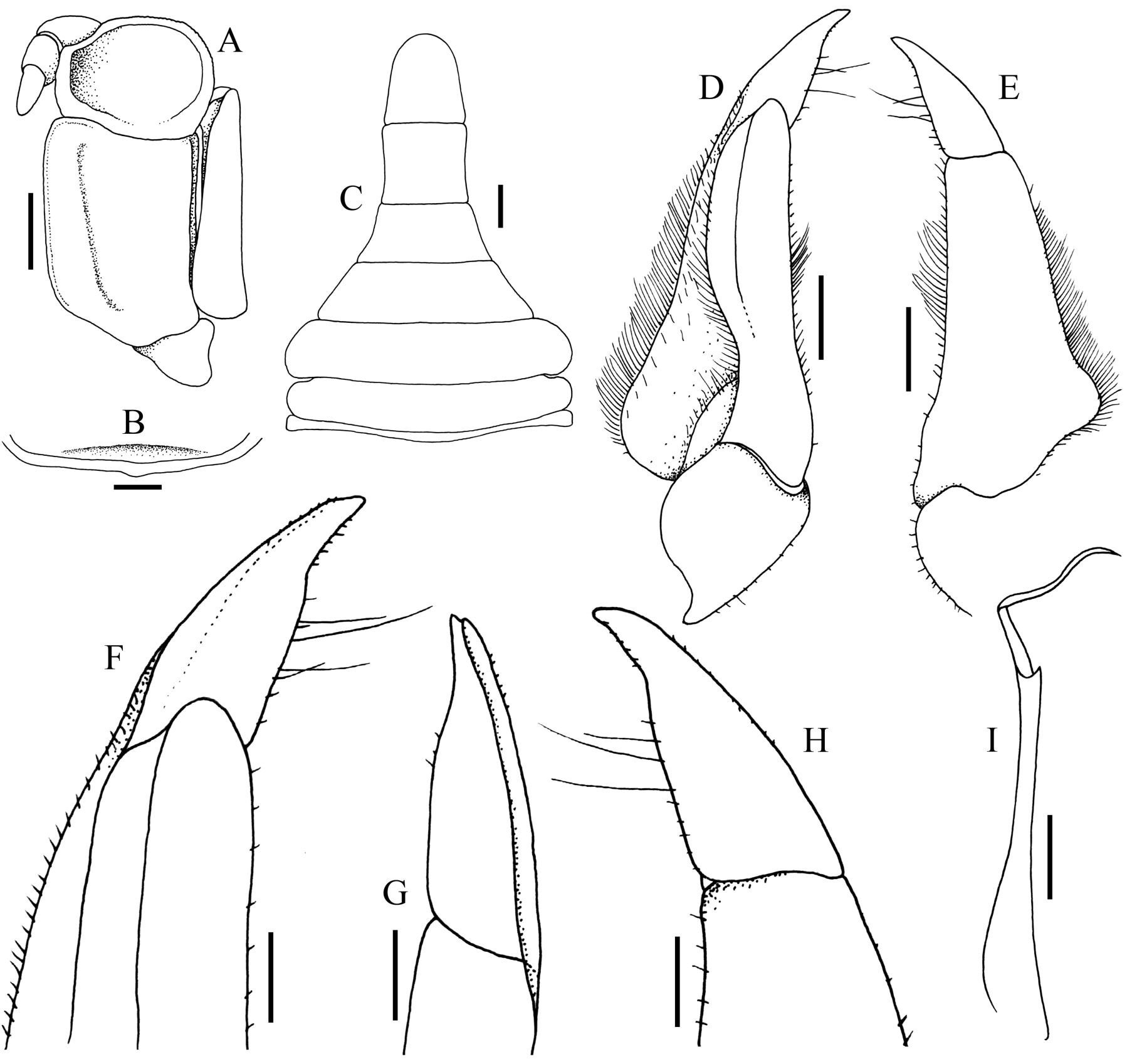

Figure 4. Sundathelphusa uva sp. nov., holotype, male $(16.1 \times 13.0 \mathrm{~mm})($ SMF-MGo 941c), Mariveles, Bataan, Luzon I. A, left third maxilliped, external view; B, front, anterior view; C, pleon (somites 1-6 \& telson), ventral view; D, left G1, pleonal view; E, left G1, sternal view; F, distal tip of left G1, pleonal view; G, distal tip of left G1, mesial view; H, distal tip of left G1, sternal view; I, left G2, pleonal view. Scales: $\mathrm{A}-\mathrm{C}=1.0 \mathrm{~mm}$; $, \mathrm{E}, \mathrm{I}=0.5 \mathrm{~mm} ; \mathrm{F}-\mathrm{H}=0.2 \mathrm{~mm}$. 
grapsoides (H. Milne Edwards, 1853) (from Luzon), S. boex $\mathrm{Ng}$ \& Sket, 1996 (from Bohol), S. cebu Husana \& Ng, 2019 (from Cebu) and an undescribed species (from Mariveles, in Luzon). They also commented that the specimen figured by Bürger (1894: pl. 1 fig. 3) as "Telphusa philippina" may be the new species from Mariveles.

We have had the opportunity to examine Bürger's material from Mariveles, now catalogued as SMF-Go 941c. This lot contains two male specimens that are evidently not conspecific with each other. One of them resembles the Telphusa philippina figured in Bürger (1894), although it is clearly not S. philippina (von Martens, 1868) sensu stricto (viz. Husana \& Ng, 2019) or S. longipes (Balss, 1937) sensu stricto (viz. Ng, 2010), but is an undescribed species (which will be treated later when the group is revised). The other male specimen in this lot is the holotype of $S . u v a$ sp. nov.

The specimen in SMF was labelled as collected by Carl Semper in "1876" but this is almost certainly incorrect. It is well known that Semper travelled and collected in the Philippines and Palau from December 1858 until his return to Germany in July 1865 (Schuberg, 1895; Samyn et al., 2013). Other workers who studied his material have also recorded some of his specimens as collected in 1876 (e.g. Ahyong \& Ng, 2007) but the dates may have been incorrectly recorded after Semper returned to Germany.

See General Discussion for taxonomy.

\section{Sundathelphusa angelito sp. nov.}

(Figs. 5, 6)

Material examined. Holotype, male $(15.3 \times 12.8 \mathrm{~mm})(\mathrm{NMCR}$ 50782), residential area along Marikina River, Barangay San Jose, Rodriguez, Rizal Province, Luzon I., Philippines, coll. M. San Andres \& H.C. Tabucal, 9 Oct. 2012.

Paratypes: 1 female $(16.7 \times 13.1 \mathrm{~mm})($ ZRC 2019.1354), same data as holotype; 4 males $(11.9 \times 9.9 \mathrm{~mm}-14.8 \times 12.0$ $\mathrm{mm}), 3$ females $(16.8 \times 13.5 \mathrm{~mm}-20.3 \times 15.9 \mathrm{~mm}),($ ZRC 2019.1355), Tungtong River, near Beverly Hills Subdivision, Antipolo, Rizal Province, Luzon I., Philippines coll. J.C.E. Mendoza \& H.G. Calilung, 3 Nov. 2011.

Others: 2 males $(12.9 \times 10.3 \mathrm{~mm}, 14.4 \times 11.2 \mathrm{~mm})($ SMFuncatalogued, ex Museum Göttingen?), Manila, no other data [old specimens].

Diagnosis. Carapace (Figs. 5A-C) subtrapezoidal, rounded, wider than long (carapace width to length ratio 1.2); anterolateral margins strongly convex, posterolateral margin distinctly concave; dorsal surface distinctly convex, mostly smooth, gastric region inflated, branchial region inflated but lower relative to gastric region in anterior view, weekly striated; epigastric, postorbital cristae poorly developed; cervical grooves moderately deep, broad; $\mathrm{H}$-shaped gastrocardiac groove well defined. Frontal median triangle (Figs. 5C, 6B) present but not sharply defined, dorsal margin not cristate, not contiguous with lateral margins; limited to central region of front. Exorbital angle broadly triangular, external margin gently convex. Epibranchial tooth small, separated from exorbital tooth by wide, shallow V-shaped gap. Male pleonal somite 6 (Fig. 6C) subrectangular, slightly longer than wide, lateral margins pronouncedly concave; telson subtriangular, basal width subequal to median height, with lateral margins straight, distinctly convergent anteriorly, apex acute but rounded. G1 (Fig. 6D-H) short, relatively stout, wide proximally, tapering towards distal tip and slightly curving laterally; terminal segment about one-third total length of G1, continuously curving laterally with subterminal segment, subconical, with distal tip abruptly narrowed, lateral margin convex, bulging distinctly; joint between terminal, subterminal segments complete, straightly transverse from sternal view. G2 (Fig. 6I) terminal segment moderately long, more than one-third total length of G2.

Etymology. The species honours Angel C. Alcala, scientist par excellence, for the mountain of work he has done on so many different aspects of Philippine and Southeast Asian biodiversity; and the immense influence he has had on so many generations of researchers in the region. The specific epithet angelito, a Filipino/Spanish diminutive of "Angel", is used as a noun in apposition.

Remarks. The recently collected specimens of $S$. angelito sp. nov. were found in small, shallow streams and canals adjacent to residential areas, hiding in the water under rocks or among submerged roots of vegetation along the stream banks. These habitats appear to receive some domestic effluents emanating from these residential areas, and there are occasional signs of varied plastic litter as well (Mendoza, pers. obs.). These suggest that $S$. angelito sp. nov. may have some level of tolerance to urban conditions.

See General Discussion for taxonomy.

\section{General Discussion}

Sundathelphusa picta (von Martens, 1868) is most similar to $S$. uva sp. nov. and $S$. angelito sp. nov. in their relatively small size (adult size at $\sim 15-20 \mathrm{~mm}$ carapace width), the generally rounded and inflated appearance of the carapace, the poorly defined frontal triangle, and the relatively short legs. It 


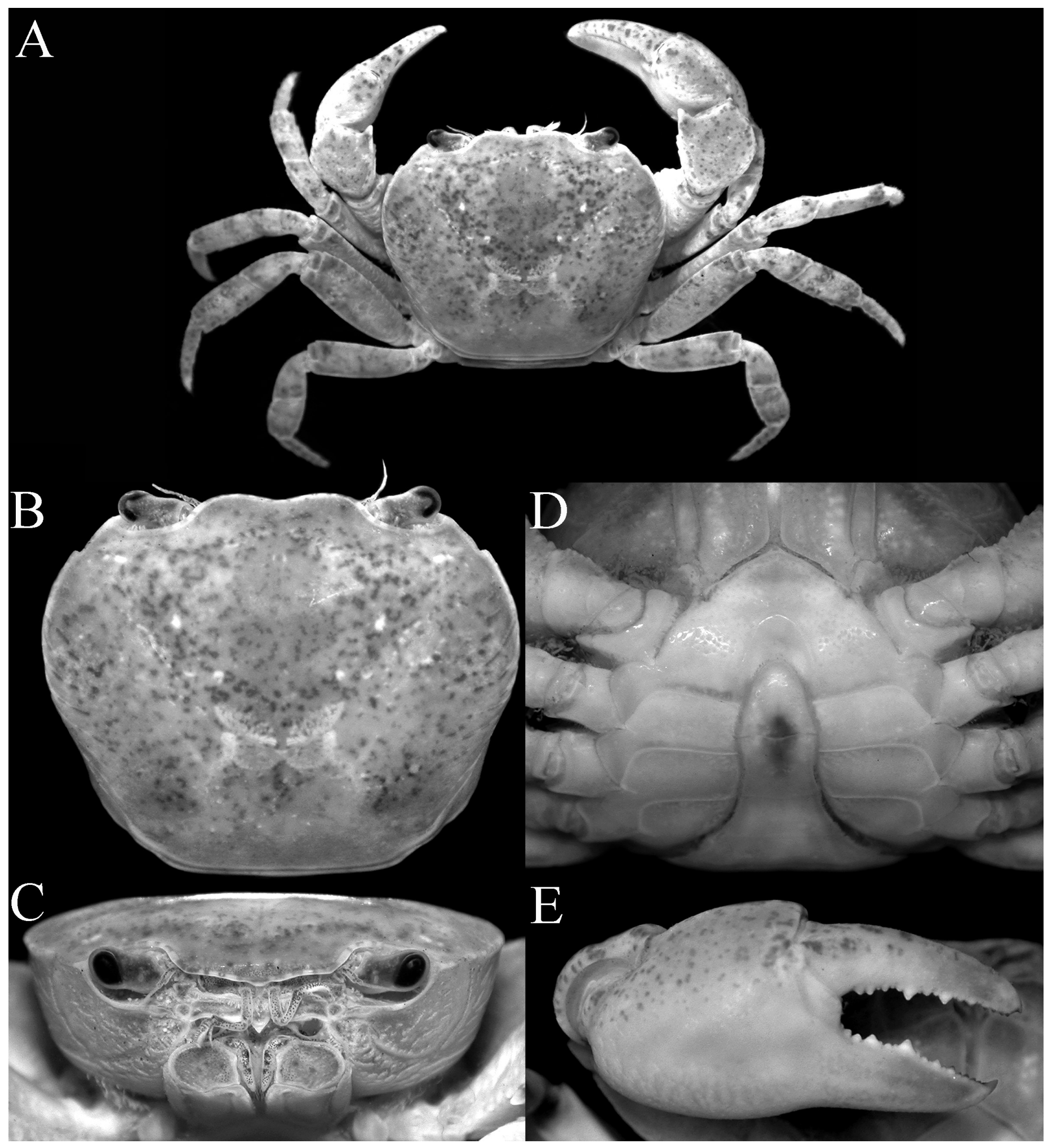

Figure 5. Sundathelphusa angelito sp. nov., holotype, male $(15.3 \times 12.8 \mathrm{~mm})(\mathrm{NMCR} 50782)$, Rodriguez, Rizal, Luzon I. A, dorsal habitus; B, carapace, dorsal view; C, carapace, anterior view; D, thoracic sternum and pleon, ventral view; E, major (right) chela, external view. 

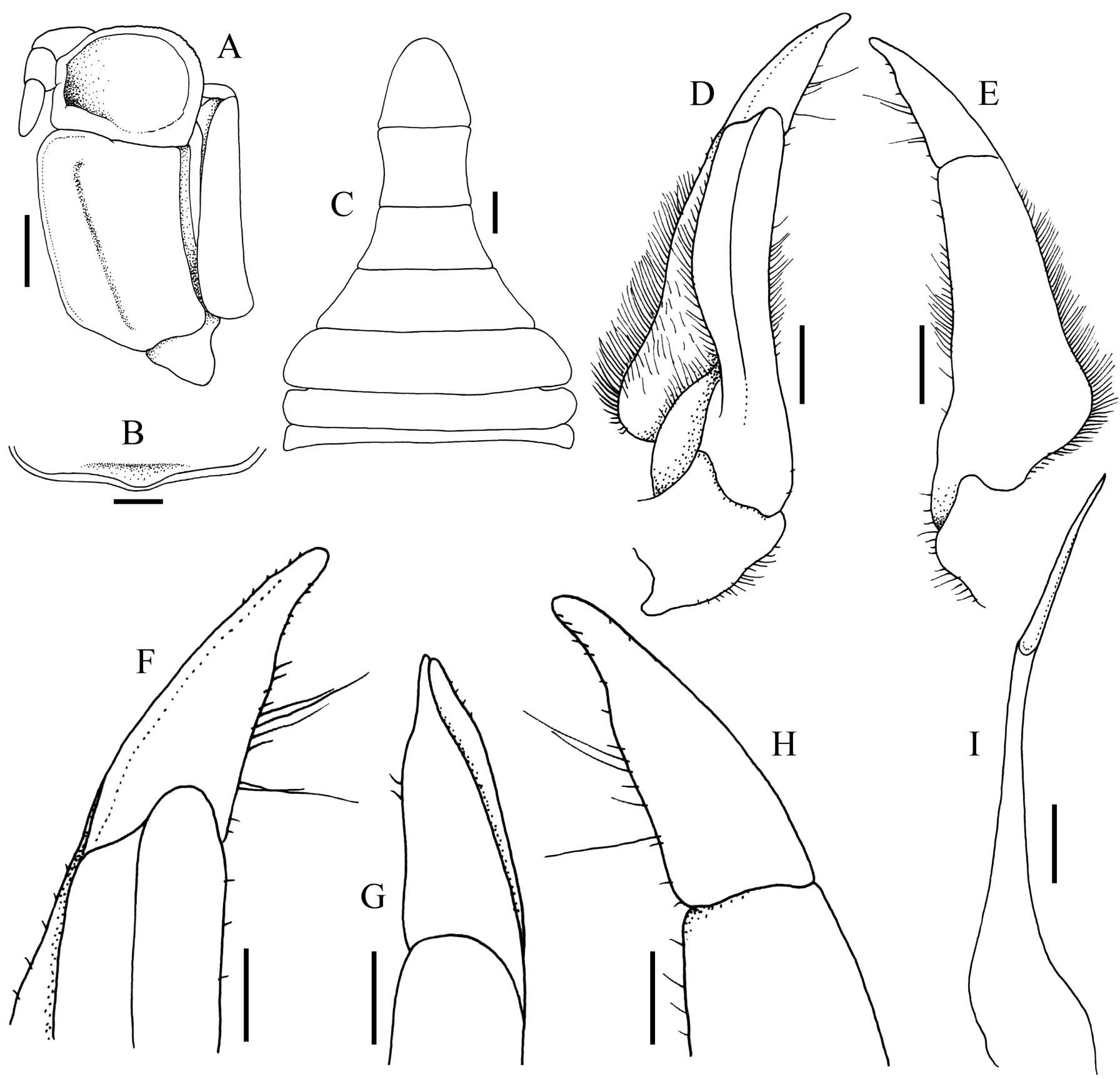

Figure 6. Sundathelphusa angelito sp. nov., holotype, male $(15.3 \times 12.8 \mathrm{~mm})(\mathrm{NMCR} 50782)$, Rodriguez, Rizal, Luzon I. A, left third maxilliped, external view; B, front, anterior view; C, pleon (somites 1-6 \& telson), ventral view; D, left G1, pleonal view; E, left G1, sternal view; F, distal tip of left G1, pleonal view; G, distal tip of left G1, mesial view; H, distal tip of left G1, sternal view; I, left G2, pleonal view. Scales: $\mathrm{A}-\mathrm{C}=1.0 \mathrm{~mm}$; $, \mathrm{E}, \mathrm{I}=0.5 \mathrm{~mm} ; \mathrm{F}-\mathrm{H}=0.2 \mathrm{~mm}$. 
differs from $S . u v a$ sp. nov. in: (1) having a higher carapace, with the branchial regions relatively more inflated in anterior view (Fig. 1C) (versus lower carapace, with branchial regions relatively lower than gastric region in anterior view; Fig. 3C); (2) having the telson of the male pleon more acutely triangular, with the lateral margins also slightly or moderately concave (Figs. 1D, 2B) (versus telson broader and more rounded at the tip, with lateral margins slightly convex in S. uva; Figs. 3D, $4 \mathrm{C}$ ); and (3) the G1 being relatively longer and more slender, with the terminal segment more slender and with a slightly concave lateral margin (Figs. 2C-E, G-J) (versus G1 relatively shorter and stouter, with the terminal segment stouter and with its lateral margin distinctly convex in $S$. uva; Figs. 4D-H).

Sundathelphusa picta differs from $S$. angelito sp. nov. in: (1) having a more extensive frontal triangle (Figs. 1C, 2A) (versus frontal triangle smaller and more limited towards center in S. angelito; Fig. 5C, 6B); (2) the male pleonal somite 6 being subrectangular, with its lateral margins slightly concave (Figs. $1 \mathrm{D}, 2 \mathrm{~B})$ (versus male pleonal somite 6 subquadrate, with lateral margins strongly concave in S. angelito; Figs. 5D, 6C); (3) the male telson being proportionally longer and narrower (Fig. 2B) (versus male telson proportionally shorter and wider in $S$. angelito; Fig. 6C); and (4) the G1 being relatively more slender, the terminal segment not having a bulging lateral margin (Figs. 2C-E, G-J) (versus $\mathrm{G} 1$ relatively stouter, terminal segment with bulging lateral margin in $S$. angelito; Figs. 6DH).Sundathelphusa uva sp. nov. differs from S. angelito sp. nov. in the following morphological characters: (1) its external orbital tooth has a proportionately shorter lateral margin (Fig. 3B) (versus longer in $S$. angelito; Fig. 5B); (2) the pterygostomial and suborbital regions are smooth (Fig. 3C) (versus distinctly rugose in $S$. angelito; Fig. 5C); (3) the male pleonal somite 6 is more elongate and its lateral margins are gently concave (Fig. 4C) (versus somite 6 more quadrate with the lateral margins more strongly concave in S. angelito; Fig. 6C); and (4) the G1, particularly the subterminal part, is proportionately stouter (Fig. 4D-H) (versus more slender in $S$. angelito; Fig. 6D-H).

\section{Acknowledgements}

The first author is grateful to the late Dr. Hans Gruner and Dr. Oliver Coleman (ZMB) as well as the late Dr. Michael Türkay (SMF) for access to their type materials. Profuse thanks are also due to Dr. Masatsune Takeda (NSMT) for letting the authors examine his material; and to Mr. Emerson Y. Sy
(Philippine Center for Terrestrial \& Aquatic Research, Manila) and Mr. Henry G. Calilung (HEDCEN \& Tungtong River Conservation Project, Antipolo) for kindly providing the type material of $S$. angelito sp. nov. The authors also thank the two anonymous reviewers for their helpful comments and suggestions.

\section{Literature Cited}

Ahyong, S.T. \& P.K.L. Ng, 2007. The pinnotherid type material of Semper (1880), Nauck (1880) and Bürger (1895) (Crustacea: Decapoda: Brachyura. Raffles Bulletin of Zoology, Supplement No. 16: 191-226.

Balss, H., 1937. Potamoniden (Dekapoda Brachyura) der Philippinen und des Malayischen Archipels. Internationale Revue der gesamten Hydrobiologie und Hydrographie, 34 (3/5): 144-187.

Bott, R., 1969. Flußkrabben aus Asien und ihre Klassifikation (Crustacea, Decapoda). Senckenbergiana biologica, 50(56): 359-366.

Bott, R., 1970. Die Süßwasserkrabben von Europa, Asien, Australien und ihre Stammesgeschichte. Eine Revision der Potamoidea und der Parathelphusoidea (Crustacea, Decapoda). Abhandlungen der Senckenbergischen Naturforschenden Gesellschaft, 526: 1-338, pls. 1-58.

Bürger, O., 1894. Beiträge zur Kenntniss der Gattung Telphusa. Zoologische Jahrbücher, 8: 1-7, pl. 1.

Davie, P.J.F., D. Guinot \& P.K.L. Ng, 2015. Anatomy and functional morphology of Brachyura. In: Castro, P., P.J.F. Davie, D. Guinot, F. R. Schram \& J. C. von Vaupel Klein (eds.). Treatise on Zoology - Anatomy, Taxonomy, Biology. The Crustacea. Volume 9C-I. Decapoda: Brachyura (Part 1). Leiden: Brill. pp. 11-163.

Husana, D.E.M., T. Kase \& J.C.E. Mendoza, 2015. Two new species of the freshwater crab genus Sundathelphusa Bott, 1969 (Crustacea: Brachyura: Gecarcinucidae) from Negros Island, Philippines. Raffles Bulletin of Zoology, 63: 226236.

Husana, D.E.M. \& P.K.L. Ng, 2019. On the identity of Sundathelphusa philippina (von Martens, 1868) (Decapoda: Brachyura: Gecarcinucidae) from the Philippines, with descriptions of two new species. Zootaxa, 4585(2): 315331.

Husana, D.E.M., M. Yamamuro \& P.K.L. Ng, 2014. Two new species of freshwater crabs of the genus Sundathelphusa Bott, 1969 (Decapoda: Brachyura: Gecarcinucidae) from caves in Luzon, Philippines. Zootaxa, 3815(4): 565-574.

Jagor, F., 1875. Travels in the Philippines. London: Chapman \& Hall. 370 pp. 
Man, J.G. De, 1892. Decapoden des Indischen Archipels. In: Weber, M., Zoologische Ergebnisse einer Reise in niederländisch Ost-Indien, Vol. 2. Leiden: E.J. Brill. pp. 265-527, pls. 15-29.

Man, J.G. De, 1902. Die von Herrn Professor Kükenthal im Indischen Archipel gesammelten Dekapoden und Stomatopoden. Abhandlungen der Senckenbergischen Naturforschenden Gesellschaft, 25: 467-929, pls. 19-27.

Martens, E. von, 1868. Über einige neue Crustaceen. Monatsberichte der Königlich Preussischen Akademie der Wissenschaften zu Berlin, 1869: 608-615.

Mendoza, J.C.E. \& T. Naruse, 2010. A new species of riverine crab of the genus Sundathelphusa Bott, 1969 (Crustacea: Brachyura: Gecarcinucidae) from northeastern Luzon, Philippines. Philippine Journal of Science, 139(1): 61-70.

Mendoza, J.C.E. \& E. Y. Sy, 2017. Sundathelphusa miguelito, a new species of freshwater crab from the southern Philippines (Brachyura, Gecarcinucidae). In: Magalhães, C., C. Becker, P.J.F. Davie, S. Klimpel, P. Martínez-Arbizu \& M. Sonnewald (eds.). Special Issue Dedicated to the Memory of Michael Türkay (1948-2015). Crustaceana, 90 (7-10) 1039-1053.

Milne-Edwards, A., 1869. Révision du genre Thelphuse et description de quelques espèces nouvelles, faisant partie de la collection du Musée. Novelles Archives du Muséum d'Histoire naturelle, 5: 161-191, pls. 8-11.

Milne Edwards, H., 1853. Mémoire sur la famille des Ocypodides. Suite (1). Deuxiéme Tribu Principale. Annales des Sciences Naturelles, $3^{\mathrm{e}}$ sér., 20: 163-228, pls. 6-11.

Ng, P.K.L., 1988. The Freshwater Crabs of Peninsular Malaysia and Singapore. Singapore: Department of Zoology, National University of Singapore \& Shinglee Press, pp. iviii, 1-156, figs. 1-63, 4 colour pls.

Ng, P.K.L., 2010. On the identity of Para-Bary-thelphusa grapsoides longipes Balss, 1937, with description of a new species from the Philippines (Brachyura, Gecarcinucidae). In: Fransen, C.H.J.M., S. De Grave \& P.K.L. Ng (eds.). Studies on Malacostraca: Lipke Bijdeley Holthuis Memorial Volume. Crustaceana Monographs, 14: 561571.

Ng, P.K.L., 2015. On a new species of Sundathelphusa Bott, 1969 (Crustacea: Brachyura: Gecarcinucidae) from southeastern Borneo. Raffles Bulletin of Zoology, 63: 494502.

Ng, P.K.L. \& A. Anker, 2016. Sundathelphusa tuerkayi, a new species of gecarcinucid freshwater crab (Crustacea: Brachyura) from Lombok Island, Indonesia. Nauplius, 24 : $1-10$, e2016026.
Ng, P.K.L., D. Guinot \& P.J.F. Davie, 2008. Systema Brachyurorum: Part 1. An annotated checklist of extant brachyuran crabs of the world. Raffles Bulletin of Zoology, Supplement No. 17: 1-286.

Ng, P.K.L. \& B. Sket, 1996. The freshwater crab fauna (Crustacea: Decapoda: Brachyura) of the Philippines. IV. On a collection of Parathelphusidae from Bohol. Proceedings of the Biological Society of Washington, 109: 695-706.

Ortmann, A.E., 1897. Carcinologische Studien. Zoologische Jahrbücher, 1898: 258-372, pl. 17.

Pretzmann, G., 1964. Studien zum System der südamerikanischen Süßwasserkrabben. Annalen des Naturhistorischen Museums in Wien, 67: 489-493, pls. 1, 2.

Rathbun, M.J., 1904. Les crabes d'eau douce (Potamonidae). Nouvelles Archives du Muséum d'Histoire naturelle, $4^{\mathrm{e}}$ sér., 6: 29-311, pls. 9-18.

Rathbun, M.J., 1905. Les crabes d'eau douce (Potamonidae). Nouvelles Archives du Muséum d'Histoire naturelle, 4 e sér., 7: 159-321, pls. 13-20.

Samyn, Y., A. Smirnov \& C. Massin, 2013. Carl Gottfried Semper (1832-1893) and the location of his type specimens of sea cucumbers. Archives of Natural History, 40.2: 324 339.

Schuberg, A., 1895. Carl Semper. Arbeiten us dem ZoologischZootomischen Institut in Würzburg, 10: 1-21. 